\title{
Seleksi Khamir Antagonis sebagai Agens Biokontrol Penyakit Bercak Daun Cercospora pada Anggrek Dendrobium
}

\author{
Selection of Antagonistic Yeasts as Biocontrol Agents \\ of Cercospora Leaf Spot Disease of Dendrobium Orchid
}

\author{
Ulfah Fahriani ${ }^{1}$, Suryo Wiyono ${ }^{1,2^{*}}$ \\ ${ }^{1}$ Departemen Proteksi Tanaman, Fakultas Pertanian IPB, Jl Meranti Darmaga, Bogor, Indonesia \\ ${ }^{2}$ Pusat Kajian Hortikultura Tropika, LPPM IPB, Jl Raya Pajajaran Baranangsiang, Bogor 16144, Indonesia
}

Diterima 9 Mei 2018/Disetujui 11 Juni 2018

\begin{abstract}
Dendrobium orchid is an ornamental that becomes an important commodity in Indonesia. Cercospora leaf spot caused by Cercospora sp. is one of the most serious problem in commercial orchid industries. Many report on potential of yeast antagonist as biological control agents has been published. This research aimed to select yeast antagonist that inhibits growth of cercospora leaf spot on orchids. Seven yeast isolates obtained from collection of Plant Clinic, IPB. Bioassay of antagonistic yeasts against leaf spot, in vitro conidial germination, and in planta were carried out. In vitro bioassay has done by counting percentages of conidial germination, in vivo bioassay has done by dipping orchid leaves in yeast cell suspension, and in planta bioassay by spraying whole plants with yeast cell suspension. The results showed that Cryptococcus albidus $Y$, Candida tropicalis Lm 13 BE, and Rhodotorula minuta Dmg 16 BEP were effective against cercospora leaf spot disease. Inhibition of conidial germination partly contributed to the biocontrol mechanism of these yeasts. Based on disease incidence, C. albidus Yp was able to control cercospora leaf spot disease by high effectiveness rate of 52.53\%. Both Ca. tropicalis Lm 13 BE and R. minuta Dmg 16 BEP showed an effectiveness rate of $34.15 \%$ and $30.04 \%$. Based on disease severity, $C$. albidus $Y p, \underline{C a} . \underline{\text { tropicalis } L m} 13 \mathrm{BE}$, and $\underline{\mathrm{R}}$ minuta Dmg $16 \mathrm{BEP}$ were able to control cercospora leaf spot disease by effectiveness rate of $55.81 \%, 53.87 \%$, and $57.60 \%$ respectively.
\end{abstract}

Keywords: biological control, Candida tropicalis, Cercospora, Cryptococcus albidus, Rhodotorula minuta.

\section{ABSTRAK}

Anggrek dendrobium merupakan tanaman hias yang menjadi komoditas penting di Indonesia. Penyakit bercak daun akibat Cercospora sp. merupakan salah satu masalah serius dalam pasar industri anggrek. Potensi khamir antagonis sebagai agens pengendali hayati telah banyak dilaporkan dalam mengendalikan penyakit. Penelitian ini bertujuan menguji dan menyeleksi khamir antagonis dalam menekan perkembangan penyakit bercak daun cercospora pada tanaman anggrek. Tujuh khamir yang digunakan merupakan khamir antagonis koleksi Klinik Tanaman, IPB. Semua isolat khamir dikaji kemampuan antagonisnya terhadap Cercospora sp. secara in vitro, in vivo, dan in planta. Uji in vitro dilakukan dengan menghitung perkecambahan konidia pada suspensi sel khamir, uji in vivo dilakukan dengan pencelupan daun anggrek ke dalam suspensi sel khamir, dilanjutkan uji in planta dengan menyemprotkan suspensi sel khamir pada tanaman anggrek. Khamir yang efektif dalam mengendalikan bercak daun cercospora adalah Cryptococcus albidus Yp. Candida tropicalis Lm 13 BE, dan Rhodotorula minuta Dmg 16 BEP. Hasil penelitian menunjukkan bahwa sebagian mekanisme yang mendasari pengendalian penyakit oleh khamir-khamir tersebut adalah hambatan dalam perkecambahan konidia. Berdasarkan kejadian penyakit, $C$. albidus Yp mampu menekan perkembangan bercak daun cercospora dengan tingkat keefektifan sebesar $52.53 \%$. Persentase tingkat keefektifan perlakuan Ca. tropicalis Lm 13 BE dan R. minuta Dmg 16 BEP adalah 34.15\% dan 30.04\%. Berdasarkan keparahan penyakit, C. albidus Yp, Ca. tropicalis Lm 13 BE, dan R. minuta Dmg 16 BEP mampu menekan perkembangan bercak daun cercospora dengan tingkat keefektifan berturut-turut sebesar $55.81 \%$, 53.87\%, dan 57.60\%.

Kata kunci: Candida tropicalis, Cercospora, Cryptococcus albidus, pengendalian hayati, Rhodotorula minuta.

\footnotetext{
* Penulis untuk korespondensi. e-mail: suryowi269@gmail.com
} 


\section{PENDAHULUAN}

Anggrek merupakan tanaman hias famili Orchidaceae yang memiliki nilai estetika dan ekonomi tinggi dengan potensi pasar yang baik. Produksi tanaman anggrek di Indonesia pada tahun 2015 mencapai 21514789 tangkai(BPS 2016). Anggrek nasional diproyeksikan akan mengalami peningkatan produksi dengan rata-rata pertumbuhan 3.71\% hingga tahun 2019 dengan produksi 23679690 tangkai (Kementan 2015a). Menurut Santoso (2006), tidak sampai 10\% dari 5000 jenis anggrek yang ada di Indonesia dibudidayakan secara komersial sehingga peluang bisnis masih sangat terbuka. Dendrobium adalah jenis anggrek yang menguasai pasar di Indonesia (Widiastoety et al., 2010).

Penyakit bercak daun cercospora (Cercospora sp.) merupakan salah satu masalah serius dalam pasar industri anggrek (Mc Millan et al., 2008). Patogen ini menyebabkan bercak yang berwarna kuning pada permukaan bawah daun. Segera setelah infeksi terjadi, bercak kuning akan timbul pada permukaan atas daun yang meluas hingga dapat menutupi seluruh permukaan daun. Infeksi berat menyebabkan daun menjadi nekrosis dan gugur lebih awal (Reddy, 2010).

Pengendaliannya dapat dilakukan dengan menyemprot daun dengan fungisida berbahan aktif metil tiofanat dan mankozeb(Reddy, 2010). Namunpenggunaanfungisidayang berkelanjutan dapat menimbulkan residu yang berdampak buruk terhadap kelestarian lingkungan (Sugiprihatini, 2009). Hal ini juga didukung oleh pemerintah dalam kebijakannya untuk menerapkan teknologi inovatif berbasis pengendalian OPT yang ramah lingkungan pada tanaman florikultura (Kementan 2015b). Sehingga diperlukan agens hayati sebagai alternatif pengendalian penyakit bercak daun cercospora pada tanaman anggrek.

Khamir merupakan mikroorganisme potensial yang digunakan sebagai agens hayati. Khamir mampu menghasilkan enzim yang berpotensi menghambat pertumbuhan patogen, serta mampu merangsang beberapa jenis respon pertahanan inang (Guetsky et al., 2002). Penggunaan khamir untuk pengendalian penyakit tanaman mulai berkembang, misalnya Cryptococcus terreus terhadap Curvularia pallescens (Wiyono dan Agustina, 2013), Pichia anomala terhadap Botryodiplodia theobromae sebagai penyebab busuk buah jambu (Hashem dan Alamri, 2009), serta aplikasi Rhodotorula minuta yang mampu menekan antraknosa (Colletotrichum acutatum) pada cabai hingga 90.17\% (Hartati, 2016). Sehingga perlu dilakukan penelitian mengenai agens biokontrol yang berpotensi mengendalikan penyakit bercak daun cercospora pada anggrek dendrobium.

\section{BAHAN DAN METODE}

\section{Tempat dan Waktu}

Penelitian dilaksanakan dari bulan April sampai Desember 2016 di Pusat Kajian Hortikultura Tropika, Lembaga Penelitian dan Pengabdian kepada Masyarakat,
Institut Pertanian Bogor (PKHT LPPM, IPB) dan Laboratorium Mikologi Tumbuhan, Departemen Proteksi Tanaman, Fakultas Pertanian, IPB.

\section{Penyiapan dan Pemeliharaan Tanaman Anggrek}

Tanaman yang digunakan adalah anggrek dendrobium berumur 1.5 sampai 2 tahun yang diperoleh dari salah satu sentra produksi anggrek terbesar di Jawa Barat, yaitu Kecamatan Gunung Sindur, Bogor. Kegiatan pemeliharaan berupa penyiraman, pemupukan, dan sanitasi tanaman.

\section{Penyediaan Khamir Antagonis}

Khamir antagonis yang digunakan merupakan koleksi Klinik Tanaman, Departemen Proteksi Tanaman. Isolat berasal dari hasil isolasi buah cabai sehat, yaitu Aureobasidium pullulans Ap, Candida tropicalis Lm 13 $\mathrm{BE}$, Pseudozyma hubeiensis $\mathrm{Ph}$, dan Rhodotorula minuta Dmg 16 BEP, dan R. minuta Rm (Hartati, 2016), serta hasil isolasi dari daun bawang merah, yaitu Cryptococcus albidus Yp dan C. terreus Yk (Wiyono dan Agustina, 2013). Isolat khamir diremajakan pada media Potato Dextrose Agar (PDA). Suspensi khamir dibuat dengan menambahkan satu lup inokulasi khamir berumur 5 hari ke dalam tabung reaksi yang berisi $10 \mathrm{ml}$ aquadest steril. Kerapatan suspensi khamir yang digunakan yaitu $10^{6} \mathrm{sel} \mathrm{mL}-{ }^{1}$.

\section{Penyediaan Suspensi Konidia Cercospora sp.}

Daun anggrek yang bergejala bercak kuning dipotong 2 $\mathrm{cm}$ x $5 \mathrm{~cm}$, diletakkan di atas sedotan yang dialasi oleh kertas tisu dalam sebuah wadah dengan keadaan lembab (RH 95\%) selama 3-4 hari. Identifikasi morfologi dilakukan dengan kunci identifikasi Barnet dan Hunter (1998). Pembuatan suspensi Cercospora sp. dilakukan dengan merontokkan konidia yang berada pada permukaan bawah daun anggrek, ditambahkan $100 \mathrm{ml}$ aquadest steril. Kerapatan suspensi konidia yang digunakan yaitu $10^{4}$ konidia $\mathrm{mL}^{-1}$.

\section{Uji Keefektifan Khamir Antagonis terhadap Perkecambahan Konidia Cercospora sp.}

Suspensi khamir $50 \mu$ diteteskan pada titik permukaan gelas obyek steril yang telah ditandai sebelumnya menggunakan spidol. Setelah dikeringanginkan, $50 \mu \mathrm{l}$ suspensi konidia diteteskan pada titik tersebut, diinkubasi di dalam cawan petri yang dilapisi dengan kertas buram lembab. Rancangan yang digunakan adalah rancangan acak lengkap (RAL), diulang tiga kali, dimana satu ulangan terdiri dari satu gelas obyek yang ditandai dengan dua titik pengamatan. Sebagai kontrol, suspensi konidia diteteskan pada gelas obyek yang tidak ditetesi khamir. Gelas obyek ditetesi oleh $50 \mu \mathrm{l}$ mankozeb formulasi $1 \mathrm{~g} \mathrm{~L}^{-1}$ sebagai pembanding. Tingkat perkecambahan konidia diamati pada 5 bidang pandang mikroskop per titik perlakuan pada 5 jam setelah perlakuan (JSP) dengan menggunakan rumus Kumar et al. (2007) sebagai berikut : 
Daya berkecambah $(\mathrm{DB})=\frac{\sum \text { konidia yang berkecambah }}{\sum \text { konidia yang diamati }} \times 100 \%$

Tingkat hambatan relatif (THR) masing-masing perlakuan terhadap daya perkecambahan konidia dihitung dengan rumus :

$\mathrm{THR}=\frac{\sum(\mathrm{DB} \text { kontrol }- \text { DB perlakuan })}{\sum \text { DB kontrol }} \quad \mathrm{x} 100 \%$

\section{Uji Hiperparasitisme Khamir Antagonis terhadap Cercospora sp.}

Suspensi konidia Cercospora sp. diteteskan pada permukaan media water agar (WA) sebanyak 100 $\mu \mathrm{l}$, diratakan menggunakan segitiga perata kemudian dikeringanginkan. Sebanyak 1 lup khamir digoreskan pada permukaan media WA tepat di tengah cawan petri (Ø $9 \mathrm{~mm})$ secara transversal. Pengamatan dilakukan terhadap interaksi yang terjadi antara khamir dengan Cercospora sp. di bawah mikroskop cahaya pada 4-6 hari inkubasi, dengan memotong media WA berbentuk persegi berukuran $1 \mathrm{~cm}^{2}$ yang dilalui oleh goresan khamir, diletakkan pada gelas obyek steril dan ditutup dengan gelas penutup steril.

\section{Uji Keefektifan Berbagai Isolat Khamir Antagonis terhadap Bercak Daun Cercospora pada Potongan Daun Anggrek}

Pengujian khamir in vivo pada daun anggrek mengacu pada metode Dan et al. (2003) yang telah dimodifikasi. Daun anggrek sehat disterilisasi permukaan dengan alkohol $70 \%$ selama 1 menit, dibilas dengan akuades steril dua kali dan dikeringanginkan. Daun dicelupkan dalam $100 \mathrm{ml}$ suspensi khamir yang telah diberi $0.02 \%$ Tween 80 . Setelah dikeringanginkan selama 1-2 jam, sebanyak $50 \mu 1$ suspensi konidia diteteskan pada permukaan bawah daun yang telah dilukai pada dua titik inokulasi. Selanjutnya, daun diinkubasi dalam wadah tertutup pada kondisi lembab (RH 95\%) dan digelapkan selama 24 jam. Setiap perlakuan diulang tiga kali, masing-masing ulangan terdiri dari dua daun. Kejadian penyakit (KP) diamati dan dihitung pada 10 hari setelah inokulasi (HSI) dengan rumus sebagai berikut :

$$
\mathrm{KP}=\frac{\sum \text { titik inokulasi dengan gejala bercak }}{\sum \text { titik inokulasi yang diamati }} \times 100 \%
$$

Lebar bercak yang dihasilkan diukur menggunakan Dino-Lite Seri AM-413T Pro. Persentase THR terhadap lebar bercak dihitung dengan rumus :

$$
\mathrm{THR}=\frac{\sum(\mathrm{LBK}-\mathrm{LBP})}{\sum \mathrm{LBK}} \times 100 \%
$$

Keterangan : LBK = lebar bercak pada kontrol, LBP = lebar bercak pada perlakuan
Uji Keefektifan Berbagai Isolat Khamir Antagonis terhadap Bercak Daun Cercospora pada Tanaman Anggrek

Suspensi khamir disemprotkan pada tanaman menggunakan hand sprayer. Lalu suspensi konidia disemprotkan pada daun setelah 24 jam aplikasi khamir, kemudian disungkup selama 48 jam. Perlakuan terdiri dari 7 khamir, kontrol positif, kontrol negatif, dan mankozeb. Rancangan yang digunakan adalah rancangan acak kelompok (RAK). Setiap perlakuan diulang empat kali, masing-masing ulangan terdiri dari satu pot tanaman anggrek. Pengamatan kejadian penyakit (KP) dihitung setiap minggu selama 5 minggu dengan rumus :

$$
\mathrm{KP}=\frac{\sum \text { daun yang menunjukan gejala bercak }}{\sum \text { daun yang diamati }} \times 100 \%
$$

Keparahan penyakit diamati setiap minggu hingga 5 minggu setelah inokulasi (MSI) dengan penilaian persentase bagian daun bergejala. Perkembangan kejadian dan keparahan penyakit dari masing-masing perlakuan dapat dibandingkan dengan dua pendekatan, pertama dengan menghitung laju infeksi penyakit sesuai dengan rumus Van der Plank (1963) sebagai berikut :

$$
r=\frac{1}{t_{2}-t_{1}}\left[\ln \frac{x_{2}}{1-x_{2}}-\ln \frac{x_{1}}{1-x_{1}}\right]
$$

Keterangan : $\mathrm{r}=$ laju infeksi penyakit bercak daun cercospora $; \mathrm{t}_{1}=$ waktu sebelum perlakuan (pengamatan awal); $\mathrm{t}_{2}=$ waktu setelah perlakuan (pengamatan akhir); $\mathrm{x}_{1}=$ kejadian/keparahan penyakit pada $\mathrm{t}_{1} ; \mathrm{x}_{2}=$ kejadian $/$ keparahan penyakit pada $\mathrm{t}_{2}$.

Tingkat keefektifan perlakuan terhadap penyakit dengan rumus Henderson dan Tilton (1955) sebagai berikut:

$$
\mathrm{EI}=\left[1 \frac{\mathrm{Ta}}{\mathrm{Ca}} \times \frac{\mathrm{Cb}}{\mathrm{Tb}}\right] \times 100 \%
$$

Keterangan : EI = tingkat keefektifan perlakuan (\%); $\mathrm{Ca}=$ kejadian/keparahan penyakit pada kontrol sebelum perlakuan; $\mathrm{Cb}=$ kejadian/keparahan penyakit pada kontrol setelah perlakuan; $\mathrm{Ta}=$ kejadian/keparahan penyakit pada perlakuan sebelum perlakuan; $\mathrm{Tb}=$ kejadian/keparahan penyakit pada perlakuan setelah perlakuan.

\section{Analisis Data}

Data yang diperoleh diolah dan dianalisis ragam menggunakan progam Microsoft Office Excel 2013 dan SPSS versi 20.0 (Statistical Package for Social Science). Pengaruh perlakuan yang berbeda nyata dilakukan uji lanjut dengan uji selang berganda Duncan (DMRT) pada taraf nyata $5 \%$. 


\section{HASIL DAN PEMBAHASAN}

Perkecambahan Konidia Cercospora sp. dengan Perlakuan Khamir

Konidia yang diberi perlakuan khamir tidak berkecambah dan menunjukkan persentase perkecambahan konidia yang lebih kecil dari kontrol pada 5 JSP (Gambar 1, Tabel 1). Konidia berkecambah pada perlakuan kontrol ditunjukkan dengan munculnya tabung kecambah dari salah satu ujung sisi konidia (Gambar 1I). Khamir mampu menghambat perkecambahan konidia diduga akibat mekanisme antibiosis berupa senyawa toksik yang dikenal dengan killer toxin (Hartati, 2016).

Persentase perkecambahan konidia tertinggi dihasilkan oleh perlakuan kontrol yaitu 32.33\% (Tabel 1). Semua perlakuan khamir secara nyata memiliki persentase perkecambahan konidia yang lebih rendah dibandingkan dengan kontrol, yaitu berkisar antara 1.50-6.00\% (Tabel 1). Apabila dibandingkan dengan perlakuan mankozeb, perlakuan khamir tidak berbeda nyata secara statistik. Secara umum perlakuan khamir dapat menekan perkecambahan konidia yang ditunjukkan dengan persentase tingkat hambatan relatif (THR) berkisar antara 84.22-89.96\%
(Tabel 2). Jika dibandingkan dengan perlakuan mankozeb, terdapat empat khamir yang memiliki THR lebih tinggi dari mankozeb, yaitu A. pullulans Ap, C. terreus Yk, $P$. hubeiensis $\mathrm{Ph}$, dan $R$. minuta Dmg 16 BEP.

\section{Hiperparasitisme Khamir Antagonis terhadap Cercospora sp.}

Semua perlakuan khamir yang diuji tidak memiliki kemampuan hiperparasitisme terhadap Cercospora sp. (Gambar 2). Hasil pengujian tidak menunjukkan tandatanda kerusakan hifa akibat perlakuan khamir. Khamir hanya menempel pada hifa dari cendawan tersebut (Gambar 2 A-G).

\section{Perkembangan Bercak Daun Cercospora pada Uji Khamir} In Vivo

Daun anggrek yang diberi perlakuan khamir dan diinokulasi Cercospora sp. menunjukkan gejala bercak yang bervariasi (Gambar 3). Kontrol positif menunjukkan gejala bercak disertai nekrosis yang tinggi (Gambar 3I). Sedangkan pada kontrol negatif tidak terjadi gejala bercak maupun nekrosis (Gambar 3J).

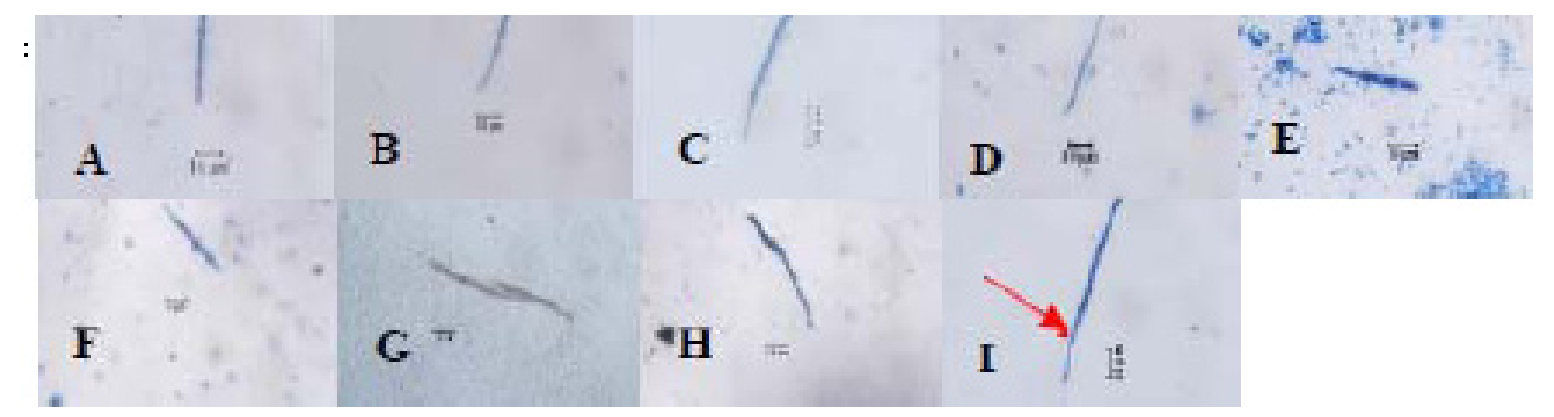

Gambar 1. Perkecambahan konidia dengan berbagai perlakuan khamir, tidak berkecambah pada perlakuan (A) A. pullulans Ap, (B) Ca. tropicalis Lm 13 BE, (C) C. albidus Yp, (D) C. terreus Yk, (E) P. hubeiensis Ph, (F) R. minuta Dmg 16 BEP, (G) R. minuta $\mathrm{Rm},(\mathrm{H})$ mankozeb, dan (I) berkecambah pada kontrol. Perbesaran 400Í (Skala bar: 10 1/4m)

Tabel 1. Pengaruh perlakuan khamir in vitro terhadap perkecambahan konidia Cercospora sp.

\begin{tabular}{|c|c|c|}
\hline Perlakuan & Perkecambahan konidia $(\%)^{\mathrm{a}}$ & THR perkecambahan konidia (\%) \\
\hline Aureobasidium pullulans Ap & $6.00 \mathrm{a}$ & 89.96 \\
\hline Candida tropicalis $\mathrm{Lm} 13 \mathrm{BE}$ & $2.35 \mathrm{a}$ & 84.22 \\
\hline Cryptococcus albidus Yp & $4.17 \mathrm{a}$ & 86.89 \\
\hline C. terreus $\mathrm{Yk}$ & $1.50 \mathrm{a}$ & 89.96 \\
\hline Pseudozyma hubeiensis $\mathrm{Ph}$ & $4.50 \mathrm{a}$ & 89.96 \\
\hline Rhodotorula minuta Dmg 16 BEP & $2.11 \mathrm{a}$ & 88.82 \\
\hline R. minuta $\mathrm{Rm}$ & $2.30 \mathrm{a}$ & 88.42 \\
\hline Mankozeb & $0.74 \mathrm{a}$ & 88.6 \\
\hline Kontrol b & $32.33 b$ & $\mathrm{TD}^{\mathrm{c}}$ \\
\hline
\end{tabular}

Keterangan: $\quad{ }^{a}$ Angka yang diikuti huruf mutu berbeda pada lajur yang sama menunjukkan hasil berbeda nyata berdasarkan uji selang berganda Duncan pada taraf nyata 5\%. ${ }^{b}$ Kontrol: perkecambahan konidia Cercospora sp. tanpa perlakuan khamir. ${ }^{\mathrm{C} T D}$ : tidak diuji. 
Berdasarkan hasil pengamatan uji khamir in vivo diperoleh kejadian penyakit yang beragam (Tabel 2). Infeksi penyakit bercak daun cercospora pada semua perlakuan menghasilkan lebar bercak yang lebih kecil dari kontrol positif. Khamir mampu menekan infeksi patogen dengan menghasilkan sekresi antifungal yang menghambat pertumbuhan patogen, seperti enzim kitinase dan $\beta$-1,3glukanase (Ippolito et al., 2000). Perlakuan R. minuta Dmg 16 BEP berpotensi menghasilkan lebar bercak terkecil dengan persentase THR sebesar 76.3\% (Tabel 2).

Perkembangan Bercak Daun Cercospora pada Tanaman Anggrek dengan Perlakuan Khamir Antagonis

Pengujian khamir in planta pada tanaman anggrek dendrobium menunjukkan gejala bercak yang beragam (Gambar 4). Secara umum perlakuan khamir tidak mengurangi insidensi penyakit pada tanaman anggrek terinfeksi bercak daun cercospora, namun beberapa perlakuan memiliki laju infeksi yang lebih rendah dibanding kontrol positif (Tabel 3).

Pengamatan laju infeksi dan tingkat keefektifan perlakuan dihitung berdasarkan kejadian dan keparahan penyakit. Berdasarkan kejadian penyakit saat 0 MSI dan 4 MSI, perlakuan khamir mampu menekan laju infeksi penyakit yang berkisar antara 0.04-0.51 unit/minggu (Tabel
3). Perlakuan C. albidus Yp berpotensi memiliki tingkat keefektifan tertinggi, yaitu 52.53\% (Tabel 3). Secara umum tanaman pada semua perlakuan mengalami perkembangan keparahan penyakit dari 0 MSI hingga 4 MSI, kecuali perlakuan $C$. albidus Yp. Keparahan penyakit tanaman akibat perlakuan $C$. albidus Yp mengalami penurunan pada 4 MSI (Gambar 5). Keparahan penyakit tertinggi saat 4 MSI terjadi pada perlakuan mankozeb, sedangkan keparahan penyakit terendah terjadi pada perlakuan kontrol negatif (Gambar 5).

Semua tanaman perlakuan mengalami laju infeksi yang lebih rendah dibanding kontrol positif. Perlakuan kontrol positif menghasilkan perkembangan penyakit tertinggi dari 0 MSI hingga 4 MSI (Gambar 5), ditunjukkan dengan laju infeksi yang paling tinggi dari semua perlakuan, yaitu 1.05 unit/minggu (Tabel 4).

Berdasarkan keparahan penyakit, semua perlakuan khamir mampu menekan laju infeksi penyakit lebih baik dari kontrol positif, berkisar antara 0.80-0.92 unit/minggu (Tabel 4). Jika dibandingkan dengan perlakuan mankozeb, khamir Ca. tropicalis Lm 13 BE, C. albidus Yp, dan R. minuta Dmg 16 BEP menunjukkan tingkat keefektifan yang cenderung lebih tinggi dari mankozeb, berturut-turut sebesar 53.87\%, $55.81 \%$, dan $57.60 \%$ (Tabel 4).

Apabila perkembangan bercak daun cercospora dihubungkan antara hasil uji in vivo dengan hasil uji in planta, perlakuan Ca. tropicalis Lm $13 \mathrm{BE}$ dan $R$. minuta

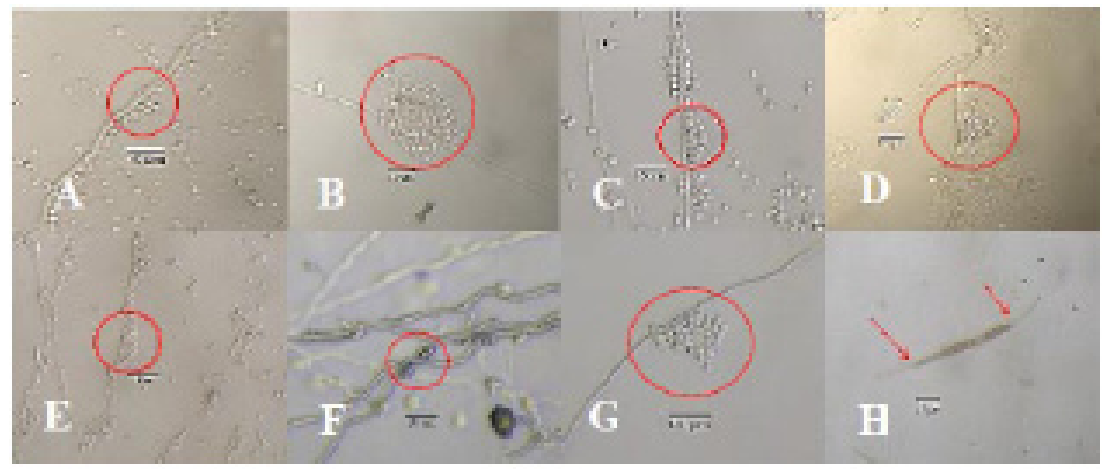

Gambar 2. Hifa tidak mengalami kerusakan akibat perlakuan berbagai isolat khamir pada uji hiperparasitisme, (A) A. pullulans Ap, (B) R. minuta Dmg 16 BEP, (C) Ca. tropicalis Lm 13 BE, (D) P. hubeiensis Ph, (E) R. minuta Rm, (F) C. terreus $\mathrm{Yk},(\mathrm{G})$ C. albidus Yp, (H) konidia berkecambah pada perlakuan kontrol. Perbesaran 400Í (Skala bar: 10 1/4m)

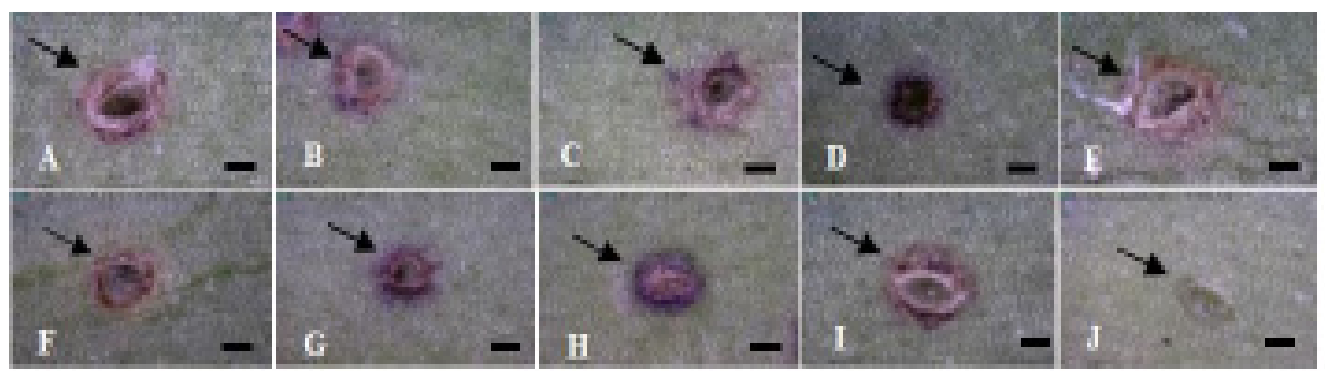

Gambar 3. Variasi lebar bercak nekrosis akibat berbagai perlakuan khamir : (A) A. pullulans Ap, (B) Ca. tropicalis Lm 13 BE, (C) C. albidus Yp, (D) C. terreus Yk, (E) P. hubeiensis Ph, (F) R. minuta Dmg 16 BEP, (G) R. minuta Rm, (H) mankozeb, (I) kontrol positif, (J) kontrol negatif. (Skala bar: $0.2 \mathrm{~mm}$ ) 
Tabel 2. Pengaruh perlakuan khamir in vivo terhadap bercak daun cercospora

\begin{tabular}{|c|c|c|c|}
\hline Perlakuan & Insiden penyakit (\%) & Lebar bercak $(\mathrm{mm})^{\mathrm{a}}$ & THR lebar bercak $(\%)^{\mathrm{a}}$ \\
\hline Aureobasidium pullulans Ap & $100.0 \mathrm{~b}$ & $0.17 \mathrm{abc}$ & $60.3 b$ \\
\hline Candida tropicalis $\mathrm{Lm} 13 \mathrm{BE}$ & $75.0 \mathrm{~b}$ & $0.11 \mathrm{ab}$ & $75.7 b$ \\
\hline Cryptococcus albidus $\mathrm{Yp}$ & $100.0 \mathrm{~b}$ & $0.18 \mathrm{bc}$ & $58.1 \mathrm{~b}$ \\
\hline C. terreus $\mathrm{Yk}$ & $94.3 b$ & $0.21 b c$ & $51.3 \mathrm{ab}$ \\
\hline Pseudozyma hubeiensis $\mathrm{Ph}$ & $73.0 \mathrm{~b}$ & $0.18 \mathrm{abc}$ & $59.4 b$ \\
\hline Rhodotorula minuta Dmg 16 BEP & $94.3 b$ & $0.10 \mathrm{ab}$ & $76.3 b$ \\
\hline R. minuta $\mathrm{Rm}$ & $83.3 b$ & $0.30 \mathrm{~cd}$ & $30.8 \mathrm{a}$ \\
\hline Mankozeb & $100.0 \mathrm{~b}$ & $0.21 b c$ & $51.2 \mathrm{ab}$ \\
\hline $\mathrm{K}+\mathrm{b}$ & $100.0 \mathrm{~b}$ & $0.44 d$ & $\mathrm{TD}^{\mathrm{c}}$ \\
\hline K-b & $0.0 \mathrm{a}$ & $0.00 \mathrm{a}$ & TD \\
\hline
\end{tabular}

Keterangan: aAngka yang diikuti huruf mutu berbeda pada lajur yang sama menunjukkan hasil berbeda nyata berdasarkan uji selang berganda Duncan pada taraf nyata 5\%. ${ }^{\mathrm{b}} \mathrm{K}+$ : Kontrol terinfeksi Cercospora sp. tanpa perlakuan khamir, K-: Kontrol sehat. 'TD: tidak diuji

Tabel 3. Kejadian penyakit bercak daun cercospora pada tanaman anggrek dendrobium

\begin{tabular}{|c|c|c|c|c|c|c|c|}
\hline \multirow{2}{*}{ Perlakuan } & \multicolumn{5}{|c|}{ Kejadian penyakit (\% daun bergejala) } & \multirow{2}{*}{$\begin{array}{c}\text { Laju infeksi } \\
\text { (unit/minggu) }^{\mathrm{a}}\end{array}$} & \multirow{2}{*}{$\begin{array}{c}\text { Tingkat } \\
\text { keefektifan }(\%)^{\mathrm{a}}\end{array}$} \\
\hline & $0 \mathrm{MSI}^{\mathrm{b}}$ & $1 \mathrm{MSI}$ & $2 \mathrm{MSI}$ & $3 \mathrm{MSI}$ & $4 \mathrm{MSI}$ & & \\
\hline Aureobasidium pullulans Ap & 23.25 & 24.75 & 24.5 & 30.75 & 41.25 & $0.49 \mathrm{a}$ & $30.48 \mathrm{a}$ \\
\hline Candida tropicalis $\mathrm{Lm} 13 \mathrm{BE}$ & 31.50 & 30.5 & 29 & 41 & 58.5 & $0.51 \mathrm{a}$ & $34.15 \mathrm{a}$ \\
\hline Cryptococcus albidus Yp & 42.25 & 40.25 & 45 & 41 & 44.75 & $0.04 \mathrm{a}$ & $52.53 b$ \\
\hline C. terreus $\mathrm{Yk}$ & 48 & 48.75 & 53.5 & 57.25 & 69.75 & $0.32 \mathrm{a}$ & $39.72 \mathrm{ab}$ \\
\hline Pseudozyma hubeiensis $\mathrm{Ph}$ & 37.75 & 40.75 & 47.25 & 48.5 & 52 & $0.45 \mathrm{a}$ & $42.44 \mathrm{ab}$ \\
\hline Rhodotorula minuta Dmg 16 BEP & 45.25 & 61 & 61.25 & 64.75 & 64.75 & $0.27 \mathrm{a}$ & $30.04 \mathrm{a}$ \\
\hline R. minuta $\mathrm{Rm}$ & 22 & 25.75 & 33.5 & 35 & 39 & $0.25 \mathrm{a}$ & $38.94 \mathrm{ab}$ \\
\hline Mankozeb & 53.25 & 52.75 & 57.5 & 56.25 & 57.5 & $0.10 \mathrm{a}$ & $48.54 \mathrm{ab}$ \\
\hline $\mathrm{K}+\mathrm{C}$ & 31.5 & 45 & 51 & 53.5 & 64.75 & $0.40 \mathrm{a}$ & $\mathrm{TD}^{\mathrm{d}}$ \\
\hline K-C & 26.5 & 25.25 & 26.5 & 26 & 41.5 & $0.43 \mathrm{a}$ & TD \\
\hline
\end{tabular}

Keterangan: angka yang diikuti huruf mutu berbeda pada lajur yang sama menunjukkan hasil berbeda nyata berdasarkan uji selang berganda Duncan pada taraf nyata 5\%. ${ }^{\mathrm{b}} \mathrm{MSI}$ : Minggu setelah inokulasi. ${ }^{\mathrm{c}} \mathrm{K}+$ : Kontrol terinfeksi Cercospora sp. tanpa perlakuan khamir, K-: Kontrol sehat. ${ }^{\mathrm{d}}$ TD: Tidak diuji.

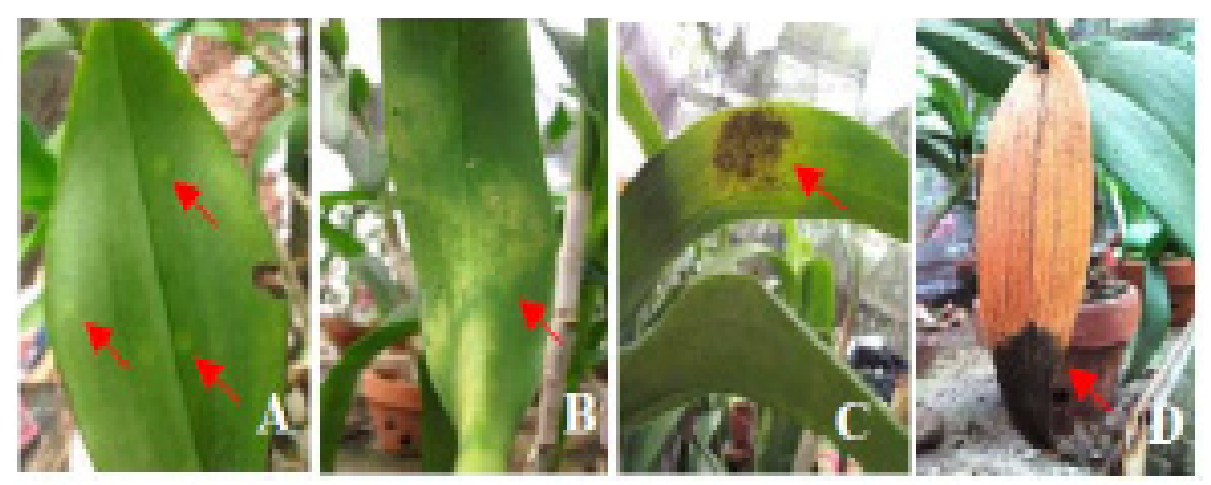

Gambar 4. Gejala bercak daun cercospora muncul pertama kali pada permukaan bawah daun (A), membentuk pola melingkar atau tidak beraturan (B), nekrosis hingga berubah warna menjadi hitam keunguan (C), infeksi berat (D). 


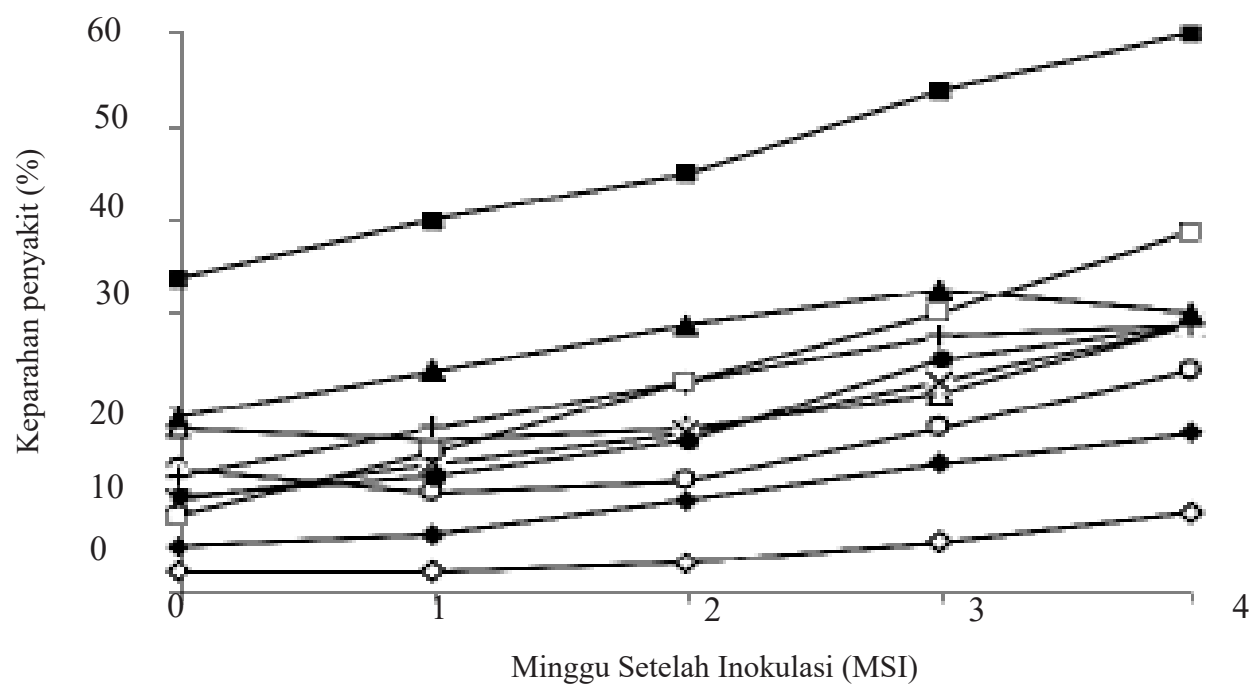

Gambar 5. Perkembangan keparahan penyakit tanaman terinfeksi Cercospora sp. dengan perlakuan khamir. pullulans Ap, $-\triangle-$ Ca.tropicalus $\mathrm{Lm} 13 \mathrm{BE}, \mathbf{- \Delta}-$ C. albidus $\mathrm{Yp}, \mathbf{-}+$ - C. terreus $\mathrm{Yk}, \mathbf{X}-$ P. hubeiensis pH, -O-R Minuta dMG 16 BEP, -๑-R. minuta Rm, $-\square-$ Mankozeb, $\square \square-$ Kontrol positif, $\mid-\diamond-$ Kontrol negatif.

Tabel 4. Laju infeksi dan tingkat keefektifan khamir terhadap penyakit bercak daun cercospora

\begin{tabular}{|c|c|c|}
\hline Perlakuan & Laju infeksi penyakit (unit/minggu) ${ }^{\mathrm{a}, \mathrm{b}}$ & Tingkat keefektifan $(\%)^{\mathrm{a}, \mathrm{b}}$ \\
\hline Aureobasidium pullulans Ap & $0.92 \mathrm{bc}$ & $29.21 \mathrm{a}$ \\
\hline Candida tropicalis $\mathrm{Lm} 13 \mathrm{BE}$ & $0.80 \mathrm{a}$ & $53.87 \mathrm{bc}$ \\
\hline Cryptococcus albidus Yp & $0.83 \mathrm{ab}$ & $55.81 \mathrm{bc}$ \\
\hline C. terreus $\mathrm{Yk}$ & $0.88 \mathrm{abc}$ & $42.84 \mathrm{abc}$ \\
\hline Pseudozyma hubeiensis $\mathrm{Ph}$ & $0.92 \mathrm{bc}$ & $45.03 \mathrm{abc}$ \\
\hline Rhodotorula minuta Dmg 16 BEP & $0.87 \mathrm{abc}$ & $57.60 \mathrm{c}$ \\
\hline R. minuta $\mathrm{Rm}$ & $0.95 \mathrm{c}$ & $37.96 \mathrm{ab}$ \\
\hline Mankozeb & $0.90 \mathrm{abc}$ & $53.40 \mathrm{bc}$ \\
\hline $\mathrm{K}+{ }^{\mathrm{b}}$ & $1.05 \mathrm{~d}$ & $\mathrm{TD}^{\mathrm{c}}$ \\
\hline $\mathrm{K}-\mathrm{b}$ & $0.91 \mathrm{bc}$ & $\mathrm{TD}$ \\
\hline
\end{tabular}

Keterangan: $\quad$ aAngka yang diikuti huruf mutu berbeda pada lajur yang sama menunjukkan hasil berbeda nyata berdasarkan uji selang

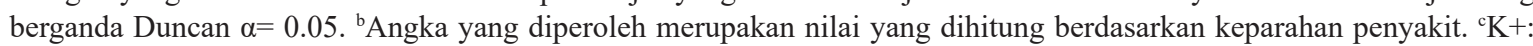
Kontrol terinfeksi Cercospora sp. tanpa perlakuan khamir, K-: Kontrol sehat. ${ }^{\mathrm{d} T D}$ : Tidak diuji

Dmg 16 BEP menghasilkan THR lebar bercak yang tinggi, yaitu $75.7 \%$ dan $76.3 \%$ (Tabel 2). Hal ini berkorelasi dengan hasil uji in planta, ditunjukkan dengan tingkat keefektifannya yang tinggi juga, yaitu $53.87 \%$ dan $57.60 \%$ (Tabel 4). Walaupun THR lebar bercak akibat perlakuan C. albidus Yp tidak setinggi Ca. tropicalis Lm 13 BE dan R. minuta Dmg 16 BEP, yaitu 58.1\% (Tabel 2), namun hasil uji in planta menunjukkan tingkat keefektifan yang cukup tinggi yaitu 55.81\% (Tabel 4). Hasil seleksi khamir antagonis menunjukkan bahwa $C$ a . tropicalis Lm $13 \mathrm{BE}, C$. albidus Yp, dan $R$. minuta Dmg 16 BEP mampu menekan perkembangan penyakit bercak daun cercospora pada tanaman anggrek dendrobium.

\section{KESIMPULAN}

Khamir antagonis mampu menekan infeksi bercak daun cercospora pada tanaman anggrek dendrobium. Secara umum perlakuan khamir menunjukkan perkecambahan konidia, lebar bercak, dan laju infeksi penyakit yang lebih rendah dibandingkan dengan kontrol terinfeksi Cercospora sp. tanpa perlakuan khamir. Berdasarkan hasil seleksi, khamir C. albidus Yp, Ca. tropicalis Lm 13 BE, dan $R$. minuta Dmg 16 BEP merupakan khamir yang efektif mengendalikan penyakit bercak daun cercospora pada tanaman anggrek. Mekanisme yang mendasari pengendalian tersebut pada penelitian ini adalah antibiosis penghambatan perkecambahan konidia. 


\section{DAFTAR PUSTAKA}

Barnet, H.L., B.B. Hunter. 1998. Illustrated genera of imperfect fungi. Fourth edition, The American Phytopathological Society. St. Paul Minnesota (US): APS Press.

[BPS] Badan Pusat Statistik. 2016. Produksi tanaman florikultura, anggrek. http://www.bps.go.id [18 Desember 2016].

Dan, H., X.D. Zheng, Y.M. Yin, P. Sun, H.Y. Zhang. 2003. Yeasts application for controlling apple postharvest diseases associated with Penicillium expansum. Bot Bull Acad Sin. 44: 211-216.

Guetsky, R., Y. Shtienberg, Y. Elad, E. Fischer, A. Dinoor. 2002. Improving biological control by combining biocontrol agents each with several mechanisms of disease suppression. Phytopathol. 92: 972-985.

Hartati, S. 2016. Khamir sebagai agens biokontrol antraknosa (Colletotrichum acutatum J.H. Simmonds) pada cabai pascapanen. Tesis. Institut Pertanian Bogor. Bogor.

Hashem, M., S. Alamri. 2009. The biocontrol of postharvest disease (Botryodiplodia theobromae) of guava (Psidium guajava L.) by the application of yeast strains. Postharvest Biol Technol. 53: 123-130.

Henderson C.F., E.W. Tilton. 1955. Tests with acaricides against the brown wheat mite. J Econ Entomol. 48(2): 157-161.

Ippolito, A, A. El-Ghaouth, M.W. Wilson. 2000. Control of postharvest decay of apple fruit by Aureobasidium pullulans and induction of defense responses. Postharvest Biol Technol 19: 265-272.

[Kementan] Kementerian Pertanian. 2015a. Outlook Anggrek. http://epublikasi. setjen.pertanian.go.id. [17 Januari 2017].

[Kementan] Kementerian Pertanian. 2015b. Rencana strategis Kementerian Pertanian tahun 2015-2019.
http://www.pertanian.go.id/file/RENSTRA 20152019.pdf. [27 Januari 2017].

Kumar, A.S., N.P.E. Reddy, K.H. Reddy, M.C. Devi. 2007. Evaluation of fungicidal resistance among Colletotrichum gloeosporioides isolate causing mango anthracnose in agri export zone of Andhra Pradesh, India. Plant Pathol Bull 16: 157-160.

Mc. Millan, R.T, A.J. Palmateer, W.A. Vendrame. 2008. Cercospora leaf spot caused by Cercospora dendrobii on Dendrobium antennatoum Lindl. and its control. Di dalam: Etxeberria E, editor. Proceedings of the Florida State Horticultural Society. Fort Lauderdale (US): Florida State Horticultural Society. 121:1-4 Juni 2008.

Reddy, P.P. 2010. Plant Protection in Horticulture. Volume 2, Fungal Diseases and their Management. Jodhpur (IN): Scientific Publishers.

Santoso, H.B. 2006. 8 Tanaman Hias Paling Populer. Agromedia Pustaka. Jakarta.

Sugiprihatini, D. 2009. Potensi penggunaan khamir dan kitosan untuk pengendalian busuk buah Lasiodiplodia theobromae (Pat.) Griffon \& Maubl. (syn. Botryodiplodia theobromae Pat.) pada buah mangga selama penyimpanan. Tesis. Institut Pertanian Bogor. Bogor.

Vanderplank, J.E. 1963. Plant Disease: Epidemics and Control. New York (US): Academic Press.

Widiastoety, D., N. Solvia, M. Soedarjo. 2010. Potensi anggrek Dendrobium dalam meningkatkan variasi dan kualitas anggrek bunga potong. $J$ Litbang Pertanian 29(3): 101-106.

Wiyono, S., E.R. Agustina. 2013. Use of yeast antagonist Cryptococcus terreus to control petal blight of dendrobium caused by Curvularia pallescens. $J$ ISSAAS 19(1): 41-48. 